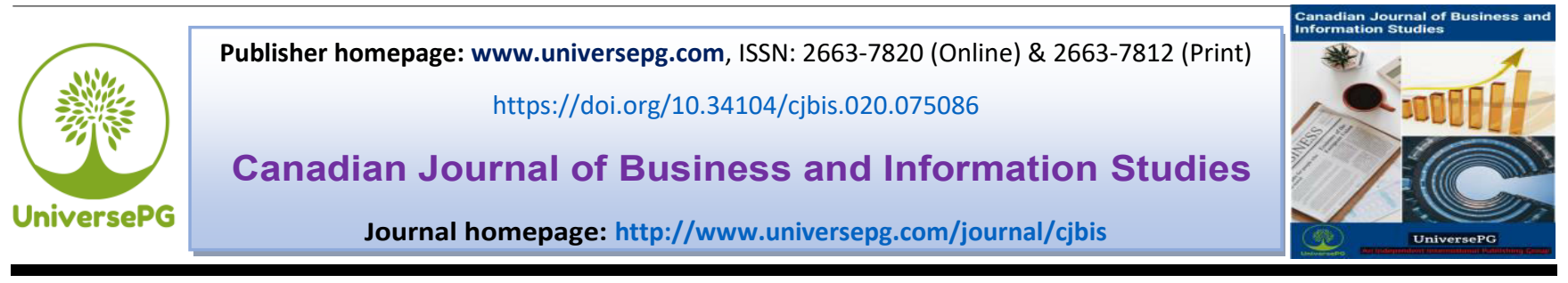

\title{
Influential Factors of Tourists' Satisfaction in Bangladesh: Evidence from Selected Tourism Destinations at Cumilla Region
}

\author{
Md. Mosharraf Hossain* \\ Department of Management Studies, Comilla University, Kotbari-3506, Cumilla, Bangladesh. \\ *Correspondence: mosharrafhossain91@yahoo.com (Md. Mosharraf Hossain, Lecturer, Department of Management \\ Studies, Comilla University, Cumilla, Bangladesh).
}

\begin{abstract}
Tourism is a developing industry around the world. Tourism industry is dynamic as it plays a momentous role in the economy of developing and developed countries. The aim of the study is to understand the influential factors of tourists' satisfaction with selected tourism destinations at Cumilla region in Bangladesh. Data are collected from 300 visitors' by survey technique through a designed questionnaire with 5-point Likert scales. Simple random sampling method is used. Data are analyzed using frequency analysis, descriptive statistics, Pearson correlation and regression analysis. From the results of regression analysis, the study is found that product, promotion, people and psychical evidence as to the vital factors, which significantly effect on tourists' satisfaction. Therefore, it is suggested that the study creates consciousness among prospective tourists, researchers, academicians, government authorities; tourism businesses, politicians, and all the stakeholders, and also the tourism industry can be benefited knowing the factors of tourists' satisfaction. Hence, the papers can be helped tourists' satisfaction advance along with tourism destinations products offer to prospect tourists.
\end{abstract}

Keywords: Tourists' satisfaction, Influential factors, Tourism industry, Cumilla region, and Bangladesh.

\section{INTRODUCTION:}

The World Tourism Organization (UNWTO) Tourism includes the activities of persons traveling to, and continuing in destinations outdoor their typical atmosphere for not more than one uninterrupted year for vacation, commercial and other drives. Conversely, tourism is the act of procedure of spending time away from home in quest of leisure, recreation, and preference, while creation use of the marketable provision of services (Nafi \& Ahmed, 2017). There are lot of service sectors in the word tourism industry is the one of them which is not only play the vital role of the country for earning the revenue but also direct effects on the social, cultural, educational, and economic sectors of national societies, and on their international relations. Bangladesh creates a remarkable feeling of a land of peace. Tourism has turn into a very significant and energetic sector in the developing countries. For the

UniversePG I www.universepg.com last two decades tourism increased very swift in the developing countries. Bangladesh has failed to introduce her as a traveler places nation in the international tourist market. In 2017 Bangladesh received only 2.17 million of foreign tourists, of which many people came for business and official purposes (Castro et al., 2017).

The GDP input Bangladesh's Tourism Revenue reached 357 USD MN in Dec 2018, compared with 348 USD MN in the previous year (Zannat, 2018; Khaled and Abedin, 2018). In compare to the others country, it is clear that there are differences in the degree of initiatives to attract tourists. For long time Bangladesh had been a tourist attracting country, but at present, its arrangement is not momentous in terms of the worldwide tourist market. Bangladesh aims to be a middle-income country by 2021 . According to Roy et al. (2017), Tourism is play the vital role for 
increasing industries around the globe and it has a vast role to the GDP in Bangladesh. Aim at this study to investigates the center factors that can influence fulfillment level of tourists with definite reference to tourism industry in the context of Bangladesh (Naushin \& Yuwanond, 2016; Kadhim et al., 2016). It is mention that satisfied tourist will revisit the same place and will provide the positive influence for potential tourist. Study found that the tourists' basically highly satisfied depends on beauty, transportation and accommodation facilities, safety and security, and costs. The country has huge potential to make money from its tourism industry (Hassan et al., 2013; Nezakati et al., 2013).

Tourism is the greatest increasing and solitary biggest industry in the world. The tourism industry of Bangladesh is of no omission from this. It can take portion in a vigorous role to supply in the countrywide economy of the country. The goal at the study an analysis on tourism marketing in Bangladesh. Specially to give an overview in tourism marketing in Bangladesh highlighting the issues and challenges are faced in this sector (Ahmmed, 2013; Bhat \& Qadir, 2013). According to Parveen (2013), Particularly for many developing countries, like the Least Developed Countries (LDCs) tourism is considered to be the one of the basic pillars of their financial enlargement. But in spite of having many predictions, the business in Bangladesh remains ignored for a long time and the share of Bangladesh in world tourism is very poor. Authority should be taken suitable steps for improvement evaluates to expand the tourist industry in Bangladesh and that way projected foreign tourist can come to Bangladesh and by that way country can earn the foreign currency. It is assumed that simultaneously those are policy maker in this division they can put more interest to catch the attention of this tourist market (Moniruzzaman \& Abedin, 2015).

Cumilla has numerous places of notice for the tourists. Since this is an ancient region, many ruins, renowned museums, ancient mosques, temples, Shalban Buddhist Bihar, Mainamati, Lalmai hill, and Commonwealth war cemetery Moreover, Shah Shuja Mosque, Dharmasagar, Pubali Circle, Kotila Mura are some of the attractions of this district. It is mention that Cumilla is one of the most central districts in Bangladesh almost 10\% tourist attractions in Chittagong division. The broad objective of the research is to study the influential factors of tourists' satisfaction of selected tourism destinations at Cumilla region in Bangladesh (Sardar et al., 2020). There are some specific objectives, which are showed below: to identify the tourism destinations at Cumilla region; to discover the factors of effect on satisfaction; to examine the factors of satisfaction of selected tourism destinations at Cumilla region in Bangladesh.

\section{Literature Review}

Bangladesh appears as a common visitor place for her natural beauty. These precious natural and cultural heritages are main parts of the tourism industry. Each year, a lot of nature adoring people visit here and add a main part in our nationwide economy. Therefore, Bangladesh has many things to current to our valuable tourists, but Archaeological and chronological tourism in the context of Bangladesh, as a portion of the larger tourism business, can be the main provider to total tourism earnings (Chowdhury \& Ahmed, 2015). Foreign travelers who come to Bangladesh, like to appreciate archaeological and chronological places first, while their second select is scenic beauty.

According to Roy \& Roy (2015), Bangladesh is occupied of ordinary beauty. Rivers, coasts and beaches, archaeological sites, religious places, hills, forests, waterfalls, tea gardens surround it. To watch the beauty, large number of home and abroad visit the country in every year according to BPC in 2012 around six-lakh tourist came in Bangladesh to enjoy its beauty (Sarker, 2015; Sarker and Begum, 2015; Sarker et al., 2012; Rahman, 2012). Total contribution in GDP was 4.4\%, 3.8\% to employment and $1.5 \%$ to investment in 2013. Owing to some limitations; Bangladesh has failed to launch itself as a tourist destination country. The main distress of the author is to highlight the factors by which Bangladesh can be one of the main tourist beautiful countries in the world in close to future. Bangladesh is gifted with historical and archaeological sites. Really the country has all the prospective to be a significant heritage intention in the world but well-planned marketing of these heritage destinations is a primary requirement to attract both foreign and domestic tourists (Hasan \& Jobaid, 2014).

According to Musa (2018), by using tourism sectors a country can earn lot of revenue. Bangladesh has most attractive tourism sectors so it has lot of opportunity to earn the revenue. Private and public administrations have come forward side by side to catch the attention of the national and international tourists, scholars, dignitaries, and foreign representatives. Out of dissimilar problems, the scholars have focused their emphasis to the marketing aspects of tourism 
area in the context of Bangladesh In adding to these; a lot of tourism related websites has been reviewed for updated information. Haque \& Islam (2015), Bangladesh is a tourism friendly nation, a renewal of tourism policy, which should be in tune with the new national financial, social, environmental policies and trends and the government should monitor all actors and factors related to tourism sector in Bangladesh (Masud, 2015).

According to Tuhin \& Majumder (2011) Tourism is a play the crucial role for development of an economy. The potential tourist selects Bangladesh there loving place for visiting attractive place because it has attractive natural beauty and rich cultural heritage but this industry fails to arrive at its objective due to sufficient marketing practices so study recommends that government should prepare a tourism policy instantly for the expansion of this industry. Tourism is play the vital role for increasing industries around the globe and it has a vast role to the GDP in Bangladesh. The aim at the article scrutinizes the center factors that can manipulate satisfaction level of tourists with definite reference to tourism industry in the perspective of Bangladesh. It is mention that satisfied tourist will revisit the same place and will provide the positive influence for potential tourist. Study found that the tourists' basically highly satisfied depends on beauty, transportation and accommodation facilities, safety and security, and costs (Roy et al., 2017).

According to Khan et al. (2017), the study provides the significance of tourism industry, idea and scope of service quality and impact of service quality on tourism and consumers satisfaction, and discovered that quality of accessibility, accommodation, venue and their dimensions contribute directly in satisfaction of tourists. The aim at this study to know the perceptions towards quality of tourism services and to ensure tourist satisfaction by examining the impact of quality tourism product on overall tourist satisfaction in this study shown that there is a significant impact of the service quality on tourist satisfaction, and therefore service quality plays an important role in tourism by increasing the level of tourist satisfaction (Ababneh, 2013). According to Laymoun et al. (2019), in this study realizes that there was positive and meaningful association between service quality and tourist satisfaction. This research aims to explore the consequence of the marketing mix and service excellence on tourist satisfaction and loyalty. Result find out by using Structural Equation Modeling (SEM). The results showed that the marketing mix had an affirmative and crucial effect on tourist's satisfaction on the other hand the service quality had a positive and significant effect on tourist's satisfaction in the specific region (Azhar et al., 2019).

\section{Conceptual model and hypotheses development}

\subsection{Product factor}

Product is anything that can be presented to a market for attention, attainment, practice, or consumption that might gratify a want or need. It comprises physical objects, services, persons, places, organizations and ideas. A product can be understood as an aggregation of the physical and psychological satisfaction it provides to the consumer. Tourism product can be demarcated as the sum total of places tourist fascinations, vehicle, and housing and entertaining (Magatef, 2015). Product is significantly effects on satisfaction (Hossain \& Khan, 2018). Realize of the study that from all the marketing mix components, the researcher studied, product \& promotion had the strongest effect on foreign tourist's satisfaction, where price and distribution were also effective significant factors. Thus, it is expected that, $H_{1}$ : Product factor and tourists' satisfaction are positively related to each other.

\subsection{Price factor}

The price of the tourism services is cost of producing, delivering and promoting the product charged by the tourism organization. Price is one of the most visible and impactful elements of the marketing mix. Price is considered as the most significant measurement of repurchase intentions. It has been proven that customers commonly buy products based on price rather than other properties. The study is inspected foreign tourists' attitude towards marketing mix features of the tourism industry in the context of Bangladesh. The study found that the perceived value of the foreign tourists relatively better than expectation. The study designated that eight out of nine factors pointedly affect international tourists' satisfaction. Only perceived price, and natural environment, which destination image had the strongest influence on satisfaction of international tourists (Khuonga et al., 2020). Thus, it is expected that, $\mathrm{H}_{2}$ : Price factor and tourists' satisfaction are positively related to each other.

\subsection{Place factor}

Place refers to the various activities the company undertakes to make the product accessible and available to target customers. It generally stands for location and accessibility. Places help to identify the 
right service. Place plays a major role in tourism field and it too provides some values in mixture with other factors to make decision to choose tourism services (Rahman et al., 2010). According to Khan et al. (2017), Tourism business plays a significant role in the economy of a nation. The study is exposed that quality of accessibility, accommodation, venue and their dimensions add directly in satisfaction of tourists. Particularly in some earlier studies, the composition of the destination qualities such as accommodation, food services, the retail and souvenir shops and destination attractions had a great impact on domestic tourists' satisfaction (Cong \& Dam, 2017). Thus, it is expected that, $H_{3}$ : Place factor and tourists' satisfaction are positively related to each other.

\subsection{Promotion factor}

Promotions have become a serious factor in the service marketing mix. Marketing communication mix (Promotion mix) contains the accurate blend of advertising, personal selling, sales promotion, public relations and direct marketing tools that the company uses to pursue its advertising and marketing objective. According to the estimates of an international study, a tourist spends $40 \%$ of his total budget on transportation, about $35 \%$ on $\mathrm{F} \& \mathrm{~B}$, and the residual on recreational activities. Effective communication, through promotion activities, spreads awareness about a destination's existence, it's intriguing and unique features, and how a person can experience it for maximum satisfaction. Promotion has positive impacts on satisfaction (Hossain \& Khan, 2018). According to (Bhat \& Qadir, 2013), actually satisfied tourists bring success to the tourism business $\&$ sometime they are likely to revisit and recommend the destination to their families and friends. In view of the growing importance of tourist satisfaction for tourism promotion, present study is an attempt to measure the satisfaction level of tourists. Thus, it is expected that, $\mathrm{H}_{4}$ : Promotion factor and tourists' satisfaction are positively related to each other.

\subsection{People factor}

People are one of the features of tourism marketing mix. People describe a service. People mean the human resource in tourism organization. It plays noteworthy role in behaving, quality control and personal selling in hospitality sector. According to (Sobari et al., 2017), as a fresh division of the tourism industry, tourism enjoys continuous growth worldwide. This is a quantitative research, result shown that, the marketing mix, of people and physical evidence, and tourism destinations effect on tourist's satisfaction, which eventually affects the loyalty. Thus, it is expected that, $H_{5}$ : People factor and tourists' satisfaction are positively related to each other.

\subsection{Process factor}

Process means a mix of tourism wellness procedures and schedules of activities and routine work. Process defines the way services are delivered by service providers. Improving the quality of the processes in any manner will in turn enhance the overall quality of the products or services. It constitutes the execution phase of any service. A faulty process will render all the efforts of other marketing mix elements useless. It is the experience which the customers pay for and would recommend in the future. The process in tourism comprise, trip planning and anticipation; travel to the site/area; recollection; trip planning packages. The trip planning packages comprise, maps, attractions en route and on site, information regarding lodging, food, quality souvenirs and mementoes. Thus, it is expected that, $H_{6}$ : Process factor and tourists' satisfaction are positively related to each other.

\subsection{Physical evidence factor}

This factor refers to the environment in which the service and any tangible goods that facilitate the performance and communication of the service are delivered. This holds great importance because the customer normally judges the quality of the service provided through it. In addition, tourism industry is play crucial role of a country so need an effective marketing structure because of consumers has vast variety of choices and also varied incentives for travel. Actually tourism is a service industry, Selected tourism areas is analyzed through the seven elements of service marketing mix, product, price, place, promotion, people, process and physical evidence. Tourists are highly satisfied product, place and process and physical evidence (Verma \& Rathore, 2018). In Tourism the physical evidence is essentially depends on travel experience, visit, and luxury. Thus, it is expected that, $\mathrm{H}_{7}$ : Physical evidence factor and tourists' satisfaction are positively related to each other.

\subsection{Tourists' satisfaction}

In tourism industry, satisfaction is a tourist's emotional state of mind after an experience. Depends on a product's perceived performance in distributing value relative to buyers' hopes. If performance 
contests expectations, the buyer is satisfied. According to (Azhar et al., 2019; Cagnina et al., 2019; Bogale \& Wondirad, 2019), the marketing mix had a positive and crucial influence on tourist's satisfaction on the other hand the service quality had a positive and significant effect on tourist's satisfaction in the particular region. According to
(Bagri \& Kala, 2015; Rahman et al., 2015), A variety of tourist activities, hospitality and safety are significant factors in determining tourist satisfaction, whereas basic facilities such as accommodation, transportation, tourism infrastructure and hygiene and sanitation at destination are of significant importance in satisfaction evaluation.

\subsection{Research model}

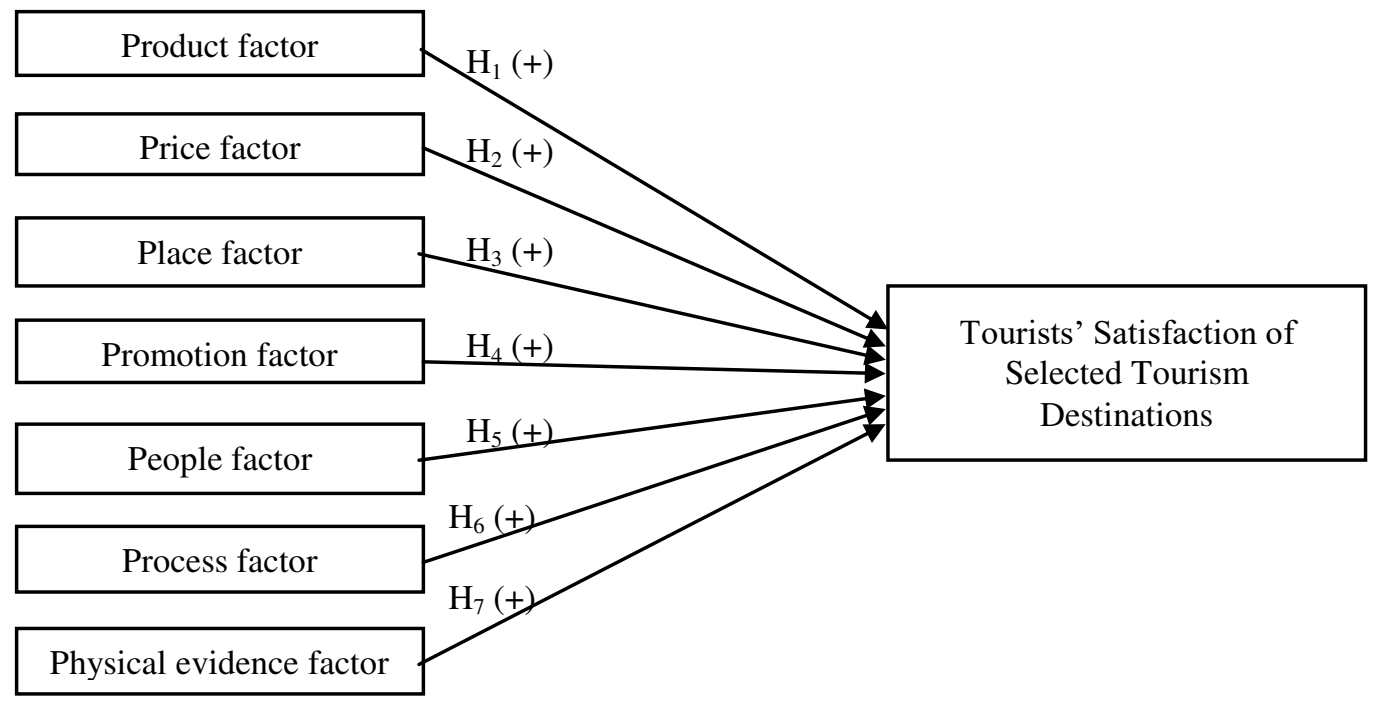

Fig 1: Conceptual model.

\section{METHODOLOGY:}

\subsection{Research types \& Design}

The present research is quantitative nature. Quantitative research is the collection of data that includes larger, more respondent's samples and numerical calculation of results. The study designs used in the study are descriptive research design. With emphasis on descriptive type, in order to conduct primary data the study will have questionnaires on the influential factors, such as Product, Price, Place, Promotion, People, Process and Physical evidence.

\subsection{Sources of data}

For collecting data both primary and secondary sources are used. The primary data is collected from the field through the administration of a structured questionnaire and personal interview. The literature review has been developed from the secondary sources in this study. Secondary data sources are those Textbooks, Different journals, Internet source, $\mathrm{PhD}$ dissertation and Annual report.

\subsection{Sampling method, Sample size \& Area}

The study is used probability sampling technique (simple random). For the study it is pertinent to be able to obtain a sample of around 300 tourists. Sample area is selected tourism destinations at Cumilla region.

\subsection{Questionnaire types \& Design}

All the questions used are closed ended. The first part is the introduction which includes the aim and the topic of the research survey. Structural questions have prepared consists of 32 items for data collections. The first section selected tourism destinations are consisting of four places including Shalban Bihar, Magic Paradise Park, Bangladesh Academy for Rural Development, and Lalmai Hill. The second section, 31 questions are regarding the influential factors of tourists' satisfaction of selected tourism destinations at Cumilla region. Thus, all variables are measured by using five point Likert scales (from 1= 'Strongly disagree' to 5= 'Strongly agree'), there is first question with four propositions which are linked to the product (natural environment, unique image, unspoiled nature \& climate conditions, safety \& security destinations), the second question with five propositions which are linked to the price (appropriate food \& drink prices, favorable handcrafted products prices, reasonable 
tours, appropriate entry prices to archaeological places, suitable ride prices), the third question with three propositions which are linked to the place/distribution (easier reached, travel agencies is sufficient to access, support services are available), the fourth question with six propositions which are linked to the promotion (public relation, sufficient online information, media enrichment, marketing campaign, promotional programs, packaging tour offering), the fifth question with three propositions which are linked to the people (friendly towards the guests, caring and cooperative, knowledgeable about service and culture), the sixth question with five propositions which are linked to the process (Creating and delivering value added products and services, service delivery and operating systems, booking, trip planning \& anticipation, consistent service delivery), the seventh question with four propositions which are linked to the physical evidence (well designed and decorated, accommodation, opportunity rest, sport facilities \& recreational activities). The number of Eighth question is tourists' satisfaction.

\subsection{Data collection}

The study is collected data from three hundreds tourists in personal interview through survey method in Bangladeshi tourists' who have already visited in selected tourist destinations at Cumilla region.

\subsection{Reliability analysis}

Cronbach's coefficient alpha to check for internal dependability of the concepts. All constructs has no problems in reliabilities if the Cronbach's Alpha values exceeded the criterion of 0.700 (Hair et al., 2010). Cronbach's Alpha is 0.795 for 31 items of variable which recommend that the survey instrument is reliable to extent all constructs consistently and free from random error.

\subsection{Data analysis}

Data are collected from tourists and encoded in SPSS 25.0 software for analysis. It is analyzed using frequency \& percentage analysis, descriptive statistics analysis (mean \& standard deviation), correlation analysis and regression analysis (Model Summary, ANOVA, Coefficients).

\section{RESULTS AND DISCUSSION:}

Table 1: Tourism destinations at Cumilla region.

\begin{tabular}{|l|l|c|c|}
\hline \multicolumn{1}{|c|}{ Variables } & \multicolumn{1}{|c|}{ Items } & F & \% \\
\hline \multirow{3}{*}{$\begin{array}{l}\text { Selected tourism } \\
\text { destinations }\end{array}$} & Shalban Bihar & 100 & 30.0 \\
\cline { 2 - 4 } & Magic Paradise Park & 50 & 20.0 \\
\cline { 2 - 4 } & Bangladesh academy for Rural Development & 100 & 30.0 \\
\cline { 2 - 4 } & Lalmai Hill & 50 & 20.0 \\
\hline
\end{tabular}

\subsection{Tourism destinations at Cumilla region}

As illustrated in Table 1, presents the different frequency and percentages of the selected tourisms. Number of 100 (30.0\%) tourists visit Shalban Bihar and Bangladesh Academy for Rural Development. Number of 50 (20.0\%) tourists visit Magic Paradise Park, and Lalmai Hill.

Table 2: Descriptive Statistics Analysis.

\begin{tabular}{|c|l|c|c|}
\hline Factors & \multicolumn{1}{|c|}{ Items } & Mean score & Stand. dev. \\
\hline \multirow{3}{*}{$\begin{array}{c}\text { Product } \\
\text { factor }\end{array}$} & Tourist destination respects the natural environment & 4.78 & 0.9673 \\
\cline { 2 - 4 } & Tourist destination has a unique image & 4.23 & 0.9992 \\
\cline { 2 - 4 } & Unspoiled nature and climate conditions & 3.97 & 1.2346 \\
\cline { 2 - 4 } & Personal safety and security in destination & 3.93 & 1.0234 \\
\hline \multirow{2}{*}{} & Prices of food and drink are appropriate & 2.34 & 1.5432 \\
\cline { 2 - 4 } & Prices of handcrafted products are favorable & 3.00 & 1.1234 \\
\cline { 2 - 4 }
\end{tabular}




\begin{tabular}{|c|c|c|c|}
\hline \multirow{3}{*}{ Price factor } & Prices of tours are reasonable & 2.01 & 1.7542 \\
\hline & Entry prices to archaeological places are appropriate & 2.23 & 1.6543 \\
\hline & Price of half ride of tools in destination is suitable & 3.13 & 1.0543 \\
\hline \multirow[b]{3}{*}{ Place factor } & The destination can be easily reached & 4.79 & 0.7845 \\
\hline & Travel agencies is sufficient to access & 4.00 & 0.8701 \\
\hline & Support services are available & 3.99 & 0.9705 \\
\hline \multirow{6}{*}{$\begin{array}{l}\text { Promotion } \\
\text { factor }\end{array}$} & Distinctive a special day for the tourism (PR) & 4.21 & 0.9324 \\
\hline & Sufficient online information & 3.92 & 1.0023 \\
\hline & Media is enriched tourism sites knowledge & 2.45 & 1.5643 \\
\hline & Tourism marketing campaigns & 3.37 & 1.4324 \\
\hline & Seminar, conference and promotional programs etc. & 3.73 & 1.3425 \\
\hline & Packaging tour offering & 4.09 & 0.9321 \\
\hline \multirow{3}{*}{$\begin{array}{l}\text { People } \\
\text { factor }\end{array}$} & The staff at destination is friendly towards the tourists & 3.52 & 1.2134 \\
\hline & Service providers are caring and cooperative & 3.14 & 1.4567 \\
\hline & Personnel are knowledgeable about service and culture & 2.19 & 1.6732 \\
\hline \multirow{5}{*}{$\begin{array}{c}\text { Process } \\
\text { factor }\end{array}$} & Create and deliver value added products and services & 4.15 & 0.1232 \\
\hline & Service delivery and operating systems are easier & 3.10 & 1.2341 \\
\hline & Making a booking at this tourist destination is relaxed & 4.19 & 0.7654 \\
\hline & Trip planning and anticipation are good & 3.79 & 1.2341 \\
\hline & Service delivery is consistent & 3.04 & 1.2134 \\
\hline \multirow{4}{*}{$\begin{array}{c}\text { Physical } \\
\text { evidence } \\
\text { factor }\end{array}$} & Places are well designed and decorated & 4.08 & 0.9923 \\
\hline & The quality of the accommodation & 3.69 & 0.8743 \\
\hline & Opportunity for rest & 4.75 & 0.7983 \\
\hline & Availability of sport facilities and recreational activities & 4.27 & 0.7913 \\
\hline
\end{tabular}

\subsection{Summary of the major variables that influence on tourists' satisfaction}

As illustrated in Table 2, the major variables that influence on tourists' satisfaction. In this table, factor mean score 4 or more \& Standard deviation is less than 1.0. Majority of the tourists are agreed with natural environment (Mean score is 4.78 \& Standard deviation is 0.9673). So, natural environment is significantly influenced on tourist satisfaction. Most of the tourists are approved in unique image (Mean score is 4.23 \& Standard deviation is 0.9992). Thus, unique image is considerably affected on tourist satisfaction. Majority of the tourists are granted in easier reached (Mean score is 4.79 \& Standard deviation is 0.7845). Hence, easier reached is appreciably affected on tourist satisfaction.

Most of the tourists are agreed with sufficient travel agencies to access (Mean score is 4.00 \& Standard deviation is 0.8701). Therefore, sufficient travel agencies are influenced on tourist satisfaction. Most of the tourists are accepted in public relation (Mean score is 4.21 \& Standard deviation is 0.9324). Therefore, public relation is significantly affected on tourist satisfaction. Most of the tourists are agreed with packaging tour offering (Mean score is 4.09 \&
Standard deviation is 0.9321 ). As a result, packaging tour offering is considerably inclined on tourist satisfaction. Most of the tourists are agreed with delivering value added products and services (Mean score is 4.15 \& Standard deviation is 0.1232 ).

Consequently, delivering value added products and services are importantly persuaded on tourist satisfaction. Most of the tourists are granted booking at this tourist destination (Mean score is 4.19 \& Standard deviation is 0.7654). As a result, booking at this tourist destination is considerably affected on tourist satisfaction. Most of the tourists are agreed with well-designed and decorated (Mean score is 4.08 \& Standard deviation is 0.9923). So, historical attractions are importantly persuaded on tourist satisfaction. Most of the tourists are granted in opportunity for rest (Mean score is 4.75 \& Standard deviation is 0.7983 ). As a result, opportunity for rest is considerably affected on tourist satisfaction. Most of the tourists are approved in sport facilities and recreational activities (Mean score is $4.27 \&$ Standard deviation is 0.7913). Thus, sport facilities and recreational activities are noticeably affected on tourist satisfaction. 
Table 3: Pearson Correlation Analysis.

\begin{tabular}{|l|c|c|c|c|c|c|c|c|}
\hline \multicolumn{1}{|c|}{ Factors } & $\mathbf{1}$ & $\mathbf{2}$ & $\mathbf{3}$ & $\mathbf{4}$ & $\mathbf{5}$ & $\mathbf{6}$ & $\mathbf{7}$ & $\mathbf{8}$ \\
\hline 1) Product factor & 1 & & & & & & & \\
\hline 2) Price factor & $.508^{* *}$ & 1 & & & & & & \\
\hline 3) Place factor & $.656^{* *}$ & $.654^{* *}$ & 1 & & & & & \\
\hline 4) Promotion factor & $.655^{* *}$ & $.476^{* *}$ & $.554^{* *}$ & 1 & & & & \\
\hline 5) People factor & $.453^{* *}$ & $.667^{* *}$ & $.556^{* *}$ & $.663^{* *}$ & 1 & & & \\
\hline 6) Process factor & $.621^{* *}$ & $.599^{* *}$ & $.578^{* *}$ & $.654^{* *}$ & $.543^{* *}$ & 1 & & \\
\hline 7) Physical evidence factor & $.654^{* *}$ & $.432^{* *}$ & $.567^{* *}$ & $.432^{* *}$ & $.467^{* *}$ & $.653^{* *}$ & 1 & \\
\hline 8) Tourist's satisfaction & $.569^{* *}$ & $.532^{* *}$ & $.679^{* *}$ & $.567^{* *}$ & $.660^{* *}$ & $.443^{* *}$ & $.696^{* *}$ & 1 \\
\hline
\end{tabular}

** Correlation is significant at 0.01 levels (2-tailed).

\subsection{Correlation analysis}

The inter-relationships between the eight variables (product factor, price factor, place factor, promotion factor, people factor, process factor, physical evidence factor, and tourists' satisfaction) are explored using Pearson correlation analysis. The average score of the multi-items for a construct is calculated and the score is used in correlation analysis. Lind et al. (2010) stated that the correlations is strong when the value is $\mathrm{r}=0.50$ to 1.0 or $\mathrm{r}=-0.50$ to -1.0 . Results in Table 3, demonstrated that all variables are correlated together at the 0.01 level using the correlation test and the values ranges $r=0.569$ to $r=0.696$. Therefore, there is no multi collinearity problem in the study.

\subsection{Results of regression analysis}

Table 4: Model Summary.

\begin{tabular}{|c|c|c|c|c|}
\hline Model & R & R Square & Adjusted R Square & Std. Error of the Estimate \\
\hline 1 & $.749^{\mathrm{a}}$ & .561 & .550 & .30282 \\
\hline
\end{tabular}

Table 5: ANOVA $^{\mathrm{a}}$

\begin{tabular}{|c|c|c|c|c|c|c|}
\hline \multicolumn{2}{|c|}{ Model } & Sum of Squares & df & Mean Square & F & Sig. \\
\hline \multirow{3}{*}{1} & Regression & 34.196 & 7 & 4.885 & 53.274 & $.000^{\mathrm{b}}$ \\
\cline { 2 - 8 } & Residual & 26.776 & 292 & .092 & & \\
\cline { 2 - 8 } & Total & 60.973 & 299 & & & \\
\hline
\end{tabular}

Table 6: Coefficients ${ }^{\mathrm{a}}$

\begin{tabular}{|c|c|c|c|c|c|c|}
\hline \multirow{2}{*}{\multicolumn{2}{|c|}{ Model }} & \multicolumn{2}{|c|}{$\begin{array}{l}\text { Unstandardized } \\
\text { Coefficients }\end{array}$} & \multirow{2}{*}{$\begin{array}{c}\begin{array}{c}\text { Standardized } \\
\text { Coefficients }\end{array} \\
\text { Beta } \\
\end{array}$} & \multirow[t]{2}{*}{$\mathbf{T}$} & \multirow[t]{2}{*}{ Sig. } \\
\hline & & B & Std. Error & & & \\
\hline \multirow{8}{*}{1} & (Constant) & 1.671 & .280 & & 5.972 & .000 \\
\hline & Product factor & .362 & .026 & .583 & 13.839 & .000 \\
\hline & Price factor & -.086 & .068 & -.054 & -1.263 & .208 \\
\hline & Place factor & .015 & .030 & .020 & .500 & .617 \\
\hline & Promotion factor & .077 & .018 & .192 & 4.202 & .000 \\
\hline & People factor & .109 & .027 & .161 & 4.072 & .000 \\
\hline & Process factor & .044 & .030 & .065 & 1.479 & .140 \\
\hline & Physical evidence factor & .121 & .041 & .145 & 2.979 & .003 \\
\hline
\end{tabular}




\subsubsection{Model Summary}

As illustrated in Table 4, the correlation coefficient value $(\mathrm{R})$ is equal to 0.749 which recommends that there is moderate positive relationship between tourists' satisfaction and influential factors (product factor, price factor, place factor, promotion factor, people factor, process factor, and physical evidence factor). Nevertheless, only $56.1 \%$ (R-square values of $0.56)$ variation in tourists' satisfaction accounted due to factors. The adjusted $r^{2}$ is 0.55 signifying that the seven factors can significantly account for $55.0 \%$ variance in the tourists' satisfaction.

\subsubsection{ANOVA}

As illustrated in Table 5, multiple regression analysis is performed to scrutinize the relationship between influential factors (product, price, place, promotion, people, process, and physical evidence) with tourists' satisfaction. Seven factors are proposed and results are computed. The F- value is 53.274 with a significant level 0.000 which is less than 0.01 with 7 and 292 degrees of freedom and it assures model fitness for regression analysis.

\subsubsection{Coefficients}

As illustrated in Table 6, the results of multiple regression analysis that product as the important factor, which significantly effects on tourists' satisfaction $(\beta 1=0.583$; $\mathrm{t}$-value $=13.839 ; \mathrm{p}<0.05)$. $\mathrm{H}_{1}$ is accepted. Therefore, product factors influenced on tourists' satisfaction. Then, promotion as the vital factor, which remarkably influences on tourists' satisfaction $(\beta 4=0.192 ; \mathrm{t}$-value $=4.202 ; \mathrm{p}<0.05) . \mathrm{H}_{4}$ is accepted. Consequently, promotion factor is persuaded on tourists' satisfaction. After, people as the important factor, which significantly impact on tourists' satisfaction $(\beta 5=0.161 ; \mathrm{t}$-value $=4.072 ; \mathrm{p}<$ 0.05). $\mathrm{H}_{5}$ is accepted. Therefore, people factor are persuaded on tourists' satisfaction. Then, physical evidence as the vital factor, which notably influences on tourists' satisfaction $(\beta 7=0.145 ; \mathrm{t}$-value $=2.979 ; \mathrm{p}$ $<0.05) . \mathrm{H}_{7}$ is accepted. So, physical evidence factor is influenced on tourists' satisfaction.

As illustrated in Table 6, the price factor negatively and insignificantly impacts on tourists' satisfaction $(\beta 2=-0.054$; $\mathrm{t}$-value $=-1.263 ; \mathrm{p}>0.05) . \mathrm{H}_{2}$ is not accepted. Therefore, price factor has no effects on tourists' satisfaction. Next, place factor insignificantly impacts on tourists' satisfaction $(\beta 3=0.020$; t-value $=0.500 ; \mathrm{p}>0.05) . \mathrm{H}_{3}$ is not accepted. Thus, place factor has no influences on tourists' satisfaction. Then, process factor insignificantly impacts on UniversePG I www.universepg.com tourists' satisfaction $(\beta 6=0.065 ; \mathrm{t}$-value $=1.479 ; \mathrm{p}>$ $0.05) . \mathrm{H}_{6}$ is not accepted. Thus, process factor has no effects on tourists' satisfaction.

\section{CONCLUSION AND IMPLICATIONS:}

Bangladesh is a country of natural beauty where the tourism as an industry has massive prospect to boost up the economy. Tourism has direct influence on educational, cultural, social and economic regions of any country and likewise on their global relations. Tourism and hospitality industries should be commended for its use of ICT and adoption of modern technologies such as social networks for engaging with customers. The application of ICT has been cunningly accomplished and realized with very insignificant cost, requiring little mechanical resource from the staff. The paper goals to generate awareness among the academicians, researchers, politicians, tourism businesses and government specialists the helpfulness of ICT application on the tourism and hospitality business (Khan \& Hossain, 2018). The drive of this study is to scrutinize the influence from tourism development on community in the PostOlympic Games era as such, the social, environmental and economic influence on local community in the Post-Olympic Games era. Suggestively, the results exposed that stakeholders would like to see more inward investment from the private part to capitalize on the upgrading and infrastructure improvements that have taken place in the area. Local industries would like more foreign tourists to stay Greenwich in particular, rather than Central London. The local community remains supportive of tourism developpment, but do urgently seek a strategy implementation that can advance their standards of living and make the most of the Olympic infrastructure for the forthcoming (Khan et al., 2018). Tourism marketing mix factor as the significant aspects that influence on tourist satisfaction. Marketing mix factor is significant in aiding destination marketers attain their determinations.

The paper goals to explore the influential factors of tourists' satisfaction of selected tourism destinations at Cumilla region in Bangladesh. The study scrutinizes factors (product, price, place, promotion, people, process and physical evidence) that influence on tourists' satisfaction. From the results of descriptive statistics analysis, the paper is exposed that natural environment, unique image, easier 
reached, sufficient travel agencies, public relation, packaging tour offering, delivering value added products and services, booking at this tourist destination, well designed and decorated, opportunity for rest, and sport facilities recreational activities as the key aspects, which significantly influenced on tourist satisfaction. From the results of regression analysis, the study is found that product, promotion, people and psychical evidence as the acute factors, which significantly influence on tourists' satisfaction. In contrast, from regression analysis, price, place and process factor don't influence on tourists' satisfaction. Thus, it is concluded that the examination creates awareness among the upcoming tourists, researchers, academicians, government authorities, tourism businesses, politicians and the stakeholders in Bangladesh and besides the tourism industry can be benefited knowing mix factor of tourists' satisfaction. Therefore, the paper can support tourists' satisfaction advance along with tourism destination products offer to potential tourists. The data may not be the real representative of overall tourists' satisfaction because of sample size and area. The paper is restricted in selected tourist destinations at Cumilla region only, and the results may not apply to other sites. Further research is instructed to develop the generalize ability of the sampling by extending the sample size and area. The study conducted in seven factors as independent variable. Therefore, there may be some other variables which may impact on tourists' satisfaction. Those factors are left for future study.

\section{ACKNOWLEDGEMENT:}

We would like to thank those who work on this topic of the research study to complete successfully.

\section{CONFLICT OF INTERESTS:}

The authors declared there are no conflicts of interest to publish the present research study.

\section{REFERENCES:}

1. Ababneh, M.A. (2013). Service Quality and its Impact on Tourist Satisfaction, Interdisciplinary Journal of Contemporary Research in Business, 4(12), 64-177.

2. Ahmmed, M.M, (2013). An Analysis on Tourism Marketing in Bangladesh, International Proceedings of Economics Development and Research (IPEDR),67(8), 35-39.

https://doi.org/10.7763/IPEDR

UniversePG I www.universepg.com
3. Azhar, E., M. Jufrizen, J. Prayogi, M. A. \& Sari, M. (2019). The Role of Marketing Mix and Service Quality on Tourist Satisfaction and Loyalty at Samosir, Independent Journal of Management \& Production (Ijm \& P), 10(5): 1662-1678.

https://doi.org/10.14807/ijmp.v10i5.937

4. Bagri, S. C. \& Kala, D. (2015). Tourists' Satisfaction at Trijuginarayan, India: An Importance Performance Analysis, Advances in Hospitality and Tourism Research (AHTR) an International Journal of Akdeniz University Tourism Faculty, 3(2),89-115.

5. Bhat, M. A. \& Qadir, N. (2013). Tourist Satisfaction in Kashmir: An Empirical Assessment, Journal of Business Theory and Practice, 1(1), 152-166.

https://doi.org/10.22158/jbtp.v1n1p152

6. Bogale, D. \& Wondirad, A. (2019). Determinant factors of tourist satisfaction in Arbaminch City and its vicinity, Southern Ethiopia, International Journal of Tourism Policy, 9(4), 1-28.

7. Cagnina, M., R. Cicero, L. Osti, L. \& Pizzuto, V. (2019). Uncontrolled positive promotion and tourists' satisfaction, Conference: XVI SIM Conference: Marketing, 4, 1-5.

8. Castro, J. C., Quisimalin, M. de Pablos, C. Gancino, V. and Jerez J. (2017) Tourism Marketing: Measuring Tourist Satisfaction. J. of Service Science and Management, 10, 280-308. https://doi.org/10.4236/jssm.2017.103023

9. Chowdhury, S. A. \& Ahmed, M. S. (2015). Archaeological and Historical Tourism: An Emerging Dimension for the Tourism Industry of Bangladesh, European Journal of Business and Management, 7(21), 1-7.

10. Cong, L.C. \& Dam, D.X. (2017).Factors affecting European tourists' satisfaction in NhaTrang City: perceptions of destination quality, International Journal of Tourism Cities, 3(4), pp. 350-362. https://doi.org/10.1108/IJTC-04-2017-0022

11. Haque, M.A. \& Islam, F. (2015). Problems and Prospects of Tourism Industry at Sylhet Region in Bangladesh, IOSR Journal of Research \& Method in Education, 5(5): 23-32.

12. Hasan, M. \& Jobaid, M. M. (2014). Heritage Tourism Marketing: Status, Prospects and Barriers, IOSR Journal of Business and Management, 16(5), 40-48.

13. Hassan, M. R., Ullah, M. M. \& Chowdhury, M.S.A. (2013). Impact of Tourism in Bangladesh Economy, World Journal of Social Sciences, 3(6), 45-57. https://doi.org/10.4236/jssm.2017.103023

14. Hossain, and Khan (2018). Green Marketing Mix Effect on Consumers Buying Decisions in 
Bangladesh, Marketing and Management of Innovations, 10(4), 298-306.

15. Kadhim, F. A., Abdullah, T. F. \& Abdullah, M. F. (2016). Effects of marketing mix on customer satisfaction: empirical study on tourism industry in Malaysia, International Journal of Applied Research, 2(2), 357-360. https://doi.org/10.13140/RG.2.2.20291.14881

16. Khaled, J. I. \& Abedin, R. (2018). Implementation of SQ Gapfil Model in Improvement of Service Quality of Hospitality Management Industries in Sylhet Region of Bangladesh, International Journal of Science and Business, 2(4),800-809.

17. Khan, M. Y. H., \& Hossain, A., (2018). The Effects of ICT Application on the Tourism and Hospitality Industries in London. Socio Economic Challenges, 4(2), 60-68.

https://doi.org/10.21272/sec.4(2).60-68.2018

18. Khan, M. Y. H., Hakeem \& Hossain, A. (2018). The Impact of Tourism Development on Greenwich Community in the Post-Olympic Games Era. Journal of Tourism Management \& Research, 3(3), 348-360.

19. Khan, F., Yusoff, R. M. \& Kakar, P. (2017). Impact of service quality and customer satisfaction on tourism industry, Journal of Advanced Research in Social and Behavioral Sciences, 6(2), 146-155.

20. Khuonga, M., N., Nguyena, N. A. T., \& Nguyena, T. M. P. (2020). Elements influence international tourists' satisfaction, Management Science Letters, 10, 2463-2476.

https://doi.org/10.5267/j.msl.2020.4.003

21. Laymoun, M.L., Alsardia, K.A \&Albattat, A. (2019). Service quality and tourist satisfaction at home stays, Management Science Letters, 10(2020), 209-216.

https://doi.org/10.5267/j.msl.2019.8.002

22. Magatef, S. G. (2015). The Impact of Tourism Marketing Mix Elements on the Satisfaction of Inbound Tourists to Jordan, International Journal of Business and Social Science, 6(7), 41-58. https://doi.org/10.5539/ijbm.v6-1n9p166

23. Masud, T. A. M. A (2015). Tourism Marketing in Bangladesh: What, Why and How, Asian Business Review, 5(1), 13-19.

24. Moniruzzaman, M. \& Abedin, M.Z. (2015). Tourism Promotional Dimension on Bangladesh Prospective, Global Journal of Management and Business Research: F Real Estate, Event \& Tourism Management .15(1), 16-22.

25. Musa, M. (2018). "Marketing" a tool to develop Bangladesh's tourism sector, International
Journal of Business, Economics and Law, 2(1), 69.

26. Nafi, S. M. \& Ahmed, T. (2017). Sustainable Tourism in Saint Martin Island: An Observation on Young Tourist Perception and Awareness Level, IOSR Journal of Humanities and Social Science (IOSR-JHSS), 22(10), 73-80. https://doi.org/10.9790/0837-2210117380

27. Naushin, S. \& Yuwanond, P. (2016). The Study of Motivation Factors of Tourists in Visiting Cox's Bazar Sea Beach, Bangladesh, PSAKU International Journal of Interdisciplinary Research, 5(1), 43-52.

28. Nezakati, H., Aziz, Y. A. Zawawi, A.D \& Sohrabinezhadtalemi, R. (2013). Making an Impact through Business and Economic Transformation Preliminary Study of $4 \mathrm{a}$ Marketing Mix Impacts on Tourists 'Satisfaction (Malaysian Food), Global Conference on Business and Economics Research, 371-378.

29. Parveen, J. A. (2013). Current Status of Tourism Industry in Bangladesh: An Empirical Evaluation, Scientific Research Journal (SCIRJ), 1(1), 41 -57.

30. Rahman, M., Islam, M. S. Amin, M. A. Sultana, R. \& Talukder, I. (2019). Effective Factors of Service Marketing Mix on Tourist Satisfaction: A Case Study, Asian Social Science; Published by Canadian Center of Science and Education, 15(7), 1-15. https://doi.org/10.5539/ass.v15n7p1

31. Rahman, M. L., Hossain, S. M. N. Miti, S. S. \& Kalam, A. K. M. A. (2010). An Overview of Present Status and Future Prospects of the Tourism Sector in Bangladesh, Journal of Bangladesh Institute of Planners, 3, 65-75.

32. Rahman, M.S. (2012). Exploring tourists' perception: the case of Bangladesh, Tourisms: an international multidisciplinary journal of tourism, 7(1), 81-98.

33. Roy, D., Dhir, M. G. M \& Ahsan, M. K. (2017). Factors Affecting Tourist Satisfaction: A Study in Sylhet Region, ABC Research Alert, 4(3)-9-20.

34. Roy, S. C. \& Roy, M. (2015). Tourism in Bangladesh: Present Status and Future Prospects, International Journal of Management Science and Business Administration, 1(8), 53-6. https://doi.org/10.18775/ijmsba.1849-56645419.2014.18.1006

35. Sardar S, Hossain ME, Hossain MI, and Islam MS. (2020). Factors affecting visitor's satisfaction: an empirical study on the Paharpur Buddha Vihara, Naogaon, Rajshahi, Int. J. Manag. Account. 2(4), 61-73.

https://doi.org/10.34104/ijma.020.061073 
36. Sarker, M. A. H. \& Begum, S. (2015). Investigating the Impact of Service Marketing Mixon Tourists' Satisfaction: An Empirical Study on Kuakata Sea Beach, Journal of Business Studies, 36(1), 245-261.

37. Sarker, M. A. H. (2015). Tourists' attitude towards service marketing mix: an empirical study on Cox'sbazar, D.U. Journal of Marketing, 16(1), 213-223.

38. Sarker, M., A. H. Aimin, W. \& Begum, S. (2012). Investigating the Impact of Marketing Mix Elements on Tourists 'Satisfaction: An Empirical Study on East Lake, European Journal of Business and Management, 4(7), 273-282. https://www.semanticscholar.org/paper/Investigatin g-the-Impact-of-Marketing-Mix-Elements-SarkerAi-min/f30ab9ef6c537efbdd1197c22e09c9c28070 adcd\#paper-header

39. Sobari., N., Usman, H. and M. I. (2017). The Influence of Information, Selection of Halal Tourism Destination, and Marketing Mix on
Tourist-Satisfaction and Loyalty, $I^{\text {st }}$ International Conference on Islamic Economics, Business, and Philanthropy (ICIEBP), 555-562.

40. Taskin, R. \& Rashid, M. M. (2018). Tourism in Kuakata, Bangladesh: Understanding Current Status and Future Prospects, Journal of Tourism and Management Research, 3(1), 235-244. https://doi.org/10.26465/ojtmr.2018319507

41. Tuhin, M. K. W \& Majumder, M. T. H. (2011). An Appraisal of Tourism Industry Development in Bangladesh, European Journal of Business and Management, 3(3), 287-298.

42. Verma R. \& Rathore, M.J.S. (2018). Analysis of Service Marketing Mix of Rajasthan a Tourist Destination, Asia Pacific Journal of Research, I (LVIV), 66 -71.

43. Zannat, N. A. (2018). Measuring Tourists' Satisfaction with Forest-Based Tourism Attractions in Sylhet: The Case of Lawachara National Park, Journal of Tourism, Hospitality and Sports, 39, 30-38.

Citation: Hossain MM. (2020). Influential factors of tourists' satisfaction in Bangladesh: evidence from selected tourism destinations at Cumilla region, Can. J. Bus. Inf. Stud., 2(4), 75-86.

https://doi.org/10.34104/cjbis.020.075086 (c) @ 